\title{
Does Brand Authenticity Alleviate the Effect of Brand Scandals?
}

Amélie Guèvremont and Bianca Grohmann

To cite this article: Guèvremont, Amélie, and Bianca Grohmann (2018), "Does Brand Authenticity Alleviate the Effect of Brand Scandals?" Journal of Brand Management, 25(4), 322-336. doi:

10.1057/s41262-017-0084-y

To link to this article: $\underline{\text { https://doi.org/10.1057/s41262-017-0084-y }}$ 
Does brand authenticity alleviate the effect of brand scandals?

\begin{abstract}
This research investigates to what extent brand authenticity lessens the impact of a brand scandal on consumer responses to the brand involved in the scandal. A $2 \times 2$ experiment shows that consumers responded more favourably to a more (vs. less) authentic brand in the event of a scandal. The protective effects of higher levels of brand authenticity emerged for emotional and behavioural brand outcomes (i.e., greater affection and willingness to pay) and brand-related inferences (i.e., lower perceived responsibility for the scandal and hypocrisy). Nonetheless, even a more authentic brand was harmed by a brand scandal (vs. no scandal). This suggests that the protective effect of brand authenticity does not fully compensate for the negative consequences of brand scandals. These findings give rise to theoretical and managerial implications.
\end{abstract}

Keywords: Brand authenticity; scandals; brand attachment; hypocrisy. 


\section{Introduction}

The marketing literature suggests that in response to the increasingly artificial nature of contemporary life (Cohen, 1988, Leigh et al, 2006), consumers seek authenticity in the experiences, products, and brands they consume (Gilmore and Pine, 2007). Consumers search for authenticity in various consumption contexts: visits of historic sites (Chronis and Hampton, 2008; Grayson and Martinec, 2004), participation in subcultures of consumption (Leigh et al, 2006; Schouten and McAlexander, 1995), consumption of reality shows (Rose and Wood, 2005), and advertisements (Beverland et al, 2008). Claims of authenticity resonate with consumers who look for the real and genuine (Fine, 2003; Grayson and Martinec, 2004; Rose and Wood, 2005).

From a branding perspective, authenticity creates a unique brand identity (Beverland, 2006; Brown et al, 2003) and favourable brand associations (Keller, 1993). Because authenticity is a promising positioning strategy, many brands communicate characteristics that suggest high levels of brand authenticity. Examples include Levi's “Authentic Stone Wash" jeans, Coca-Cola branding around "The real thing", or Beck's use of the original 1873 beer recipe (Gundlach and Neville, 2012). From a consumer perspective, authentic brands are perceived as honest, genuine, and dependable (Alexander, 2009; Gilmore and Pine, 2007); they reflect continuity through time and help consumers define their identity (Morhart et al, 2015). Research has examined the nature of brand authenticity (Morhart et al, 2015; Napoli et al, 2014; Gundlach and Neville, 2012), the consequences of an authentic brand image (Eggers et al, 2013; Guèvremont and Grohmann, 2016; Morhart et al, 2015; Napoli et al, 2014), and the relational 
component of brand authenticity in terms of brands being real in their interactions with consumers (Ilicic and Webster, 2014).

Although the literature on the nature and consequences of brand authenticity has made considerable progress, it has not examined the impact of brand authenticity on brands that face challenges, such as the event of a brand scandal. Brand scandals entail negative consequences in terms of consumer reactions (e.g., purchase intentions; Huber et al, 2010) and brand-related outcomes (e.g., brand equity; Dawar and Pillutla, 2000; Hegner et al, 2014). Understanding the consequences of brand scandals is important because consumers demand greater transparency from firms (Brady, 2003; Holt, 2002). Because authentic brands are perceived as honest and credible (Morhart et al, 2015) and are associated with high expectations of transparency (Gilmore and Pine 2007), their involvement in brand scandals may be particularly harmful. On the other hand, it is also possible that brand authenticity cushions the impact of scandals on consumer responses to the brand in case of a scandal.

The objective of this article is to empirically test the impact of an ethical scandal (i.e., use of child labour, poor working conditions) on consumer responses towards brands associated with higher versus lower levels of brand authenticity. This research examines multiple consumer responses (i.e., affection, willingness to pay) and brand-related inferences (i.e., perceived responsibility and hypocrisy) following a scandal, and explores the mediating role of affection, responsibility, and hypocrisy.

This article contributes several new insights. First, it extends brand authenticity research to a new context and considers outcome variables that go beyond consumers' attitudes and purchase intentions (Napoli et al, 2014) by considering willingness to pay, 
affection, perceived hypocrisy, and responsibility. This article also clarifies to what extent perceived hypocrisy, responsibility, and affection mediate the interactive effect of brand authenticity and presence of a scandal on willingness to pay.

Second, this research contributes to the literature on scandals in that it identifies brand authenticity as a moderator of the effect of scandals on consumer responses. Although there is evidence that a positive pre-scandal corporate reputation attenuates the negative consequences of a scandal (Coombs and Holladay, 2006; Dean, 2004), this research uniquely considers the moderating effect of an authentic brand image. This consideration of brand image is of strategic value, because brand image is more easily crafted than corporate reputation (Bennett and Gabriel, 2003).

Third, this research adds to the brand relationship literature, which proposes that brand commitment plays a critical role in inducing consumer resistance to negative information about the brand (Aaker et al, 2004; Fournier, 1998). By predicting a protective effect of brand authenticity when a scandal occurs - justified by the ability of authenticity brands to create connections and commitment with consumers (Morhart et al, 2015)—, this research highlights the positive effects of consumer-brand relationship in a brand scandal context (Aaker et al, 2004; Fournier, 1998).

This article is organized as follows: A literature review pertaining to brand scandals and brand authenticity leads up to hypotheses regarding a protective effect of brand authenticity in a brand scandal context. This article includes two pretests to validate the manipulations, and an experiment to test the hypotheses. It ends with a discussion of theoretical and managerial implications, limitations, and future research directions. 


\section{Theoretical background}

\section{The influence of scandals}

Brands are sometimes implicated in misconduct, crises, and scandals (Ahluwalia et al, 2000; Roehm and Brady, 2007). Such incidents disappoint consumers' expectations of the brand and have negative consequences for the brand's reputational and financial assets (Coombs, 2007; Huber et al, 2010). Detrimental consequences of scandals include lower purchase intentions (Huber et al, 2010), revenue losses (Cleeren et al, 2013), deterioration of brand equity (Dawar and Pillutla, 2000; Hegner et al, 2014), negative brand perceptions (Huber et al, 2010), and decreased effectiveness of marketing activities (Van Heerde et al, 2007).

Different types of scandals have been studied in the literature. Performance and product-related scandals relate to the ability of the brand to deliver functional benefits (Dawar and Pillutla, 2000), such as in the case of defective products (e.g., Toyota's faulty brakes leading to recalls). Product-related scandals have attracted considerable interest in the literature (Cleeren et al, 2013; Dawar and Lei, 2009; Hegner et al, 2014; Klein and Dawar, 2004; Laufer and Coombs, 2006; Pullig et al, 2006; Roehm and Brady, 2007). Values-related scandals relate to social and ethical issues pertaining to brand values (Huber et al, 2010; Trump, 2014), such as Nike's use of child labour.

This article focuses on a values-related (hereinafter referred to as ethical) brand scandal. Compared to product-related scandals (Dawar and Pullitla, 2000; Pullig et al, 2006), ethical scandals have received less attention in the literature. Because consumers increasingly scrutinize and severely punish unethical brand behaviours (Brunk, 2012), it 
is important to better understand the impact of ethical scandals on consumer responses.

\section{Moderators of brand scandal effects}

Although scandals generally hurt brands, moderators influence the magnitude of this effect. In the context of ethical scandals, moderators include consumer commitment, selfrelevance of the issue, duration of the consumer-brand relationship, attitude certainty, and brand personality (Huber et al, 2010; Huber et al, 2011; Hegner et al, 2014; Pullig et al, 2006; Trump, 2014). For example, highly committed consumers are less tolerant of brand transgressions, particularly when the transgression domain is of high self-relevance (e.g., discrimination against women is more relevant for women; Trump, 2014). In the context of product-harm crises, moderators of brand scandal effects include brand familiarity, country of origin, brand response, and anthropomorphization (Cleeren et al, 2008, Dutta and Pullig, 2011, Laufer et al, 2009, Puzakova et al, 2013, Samaraweera et al 2014). For example, a negative country of origin increases blame attributions to the brand when consumer familiarity with the brand involved in a product-related crisis is low (Laufer $e t$ $a l, 2009)$.

A moderator of scandal effects that has attracted considerable interest is corporate reputation. Corporate reputation generally captures stakeholders' evaluation of an organization (Gotsi and Wilson, 2001). It is defined as an "aggregation of a single stakeholder's perceptions of how well organizational responses are meeting the demands and expectations of many organizational stakeholders" (Wartick, 1992, p. 34). Corporate reputation is built over time through interactions and communication between organizations and their stakeholders (Fombrun and Van Riel, 2004; Robert and Dowling, 
2002).An organization's reputation consists of its corporate ability (i.e., "expertise in producing and delivering product and/or service offerings", Brown and Dacin, 1997, p. 70) and corporate social responsibility (i.e., the "character of the company, usually with regard to important societal issues", Brown and Dacin, 1997, p. 70). Importantly, a good corporate reputation exerts a protective effect in case of a scandal (e.g., Ahluwalia et al, 2000; Coombs and Holladay, 2006; Dawar and Pillutla, 2000).

This article considers brand authenticity as a moderator of consumer responses to a brand scandal. Brand authenticity differs from corporate reputation in fundamental ways: First, brand authenticity is a brand image component. Brand image describes the position of a brand in the market in terms of how consumers see it (Ghodeswar, 2008; Nandan, 2005).An authentic brand image reflects consumers' beliefs about high levels of brand credibility, continuity, integrity, and symbolism (Morhart et al, 2015). Brand authenticity differs from corporate reputation in the sense that it contributes to an organization's reputation (De Chernatony, 1999; Fombrun and Van Riel, 2004), but represents only one of several elements involved in the emergence of an organization's reputation. Other elements include a firm's corporate social responsibility policies (Ellen et al, 2006), financial records (McGuire et al, 1988) or employment practices (Fombrun and Shanley, 1990). Corporate reputation is thus broader in scope.

Second, brand authenticity and corporate reputation differ in that the former is more malleable from a strategic viewpoint (e.g., through communications; Beverland et al, 2008), whereas the latter is built through cumulative assessements of an organization's actions by its stakeholders over time (Fombrun and Shanley, 1990). Corporate reputation is thus less influenced by short-term strategies (Bennett and Gabriel, 2003). Third, 
corporate reputation is an evaluative assessment (i.e., bad vs. good; Dean, 2004). Brand authenticity, on the other hand, represents the degree of a brand image characteristic perceived by consumers (i.e., low vs. high authenticity; Morhart et al, 2015). Image and reputation differ in that image is a perception whereas reputation is a judgment (Barnett et al 2006). Thus, consumers generally value a corporation with a good reputation, whereas they may not necessarily appreciate a brand's image of authenticity (Guèvremont and Grohmann, 2016). Fourth, an organization's reputation is often measured on objective criteria, such as its financial performance (Black et al, 2000; Laufer and Coombs, 2006). Brand authenticity reflects consumers' perceptions of a brand's authenticity levels and is measured by asking consumers to position the brand on characteristics related to its authenticity (Morhart et al, 2015). Overall, considering that brand authenticity and corporate reputation differ in nature, scope, and measurement, it is worthwhile to investigate the moderating role of brand authenticity independently from that of corporate reputation.

\section{Brand authenticity as a moderator of consumer responses to brand scandals}

The literature suggests that consumers look for authenticity in their consumption experiences — which includes the brands they consume (Arnould and Price, 2000; Napoli et al, 2014). Consumers are looking for authenticity to cope with the inauthentic nature of contemporary world (Cohen, 1988). In the marketplace, many brands claim to be authentic to attract consumers and to be perceived as relevant resources (Beverland et al, 2008; Gundlach and Neville, 2012). An authentic brand is a brand that consumers perceive as real and sincere (Alexander, 2009; Gilmore and Pine, 2007), and motivated 
by a genuine passion (Beverland et al, 2008). Authentic brands are committed to quality, maintain a connection to place, and are grounded in history (Beverland, 2006; Gundlach and Neville, 2012). Consumers connect with authentic brands on an emotional level, because such brands are symbolic resources that help them define who they are and construct their self-concept (Morhart et al, 2015). A recent conceptualization focuses on brand authenticity along four dimensions: continuity, credibility, integrity, and symbolism (Morhart et al, 2015). An authentic brand is dependable, cares for its consumers, helps them construct their identity, and reflects continuity from the past into the future.

Overall, brand authenticity is associated with favourable responses: consumers are more inclined to purchase authentic brands (Napoli et al, 2014) and are more willing to talk positively about such brands to others (Morhart et al, 2015). Brand authenticity relates positively to emotional brand attachment (Guèvremont and Grohmann, 2016), brand trust (Eggers et al, 2013), and brand choice likelihood (Morhart et al, 2015). Although research supports positive reactions to brand authenticity, individual and contextual variables moderate this relation (Guèvremont and Grohmann, 2016).

In line with the positive consequences of brand authenticity documented in prior research, this article examines to what extent brand authenticity protects the brand in the case of a brand scandal. A strong argument for a protective effect of brand authenticity in a brand scandal context arises from the consumer-brand relationship literature (Fournier, 1998). This literature suggests that consumer resistance to negative information about a brand increases with brand commitment—a central component of strong consumer-brand relationships (Aaker et al, 2004). Consumers who have formed a strong relationship with 
a brand are isolated from the impact of negative information and are therefore more forgiving (Ahluwalia et al, 2000; Ahluwalia et al, 2001; Hegner et al, 2014). Highly committed consumers counterargue brand-related negative information to a greater extent to maintain their positive attitude toward the brand.

Recent work suggests that authentic brands lend themselves to the creation of emotional connections with consumers (Guèvremont and Grohmann, 2016; Morhart et al, 2015). Authentic brands' potential to evoke strong consumer-brand relationships arises because authentic brands represent important resources that help consumers reveal their true selves (Beverland and Farrelly, 2010). The symbolism of authentic brands (i.e., their relevance in terms of identity construction by reflecting significant values; Morhart et al, 2015) is likely to increase consumers' connections with such brands, considering that the self-concept must be involved for the development of strong relations that include high levels of commitment (Park et al, 2010). Authentic brands are further associated with integrity and sincerity (Beverland 2006; Napoli et al, 2014) — traits that represent the foundation of enduring relationships (Aaker et al, 2004). In sum, the perspective that authentic brands create strong bonds with consumers suggests a protection effect in the presence of a scandal because consumers' commitment to the brand shields them from negative information about the brand.

This article considers affection towards the brand and willingness to pay as consumer responses to the brand. Affection is a component of the emotional attachment felt towards a brand (Thomson et al, 2005) and positively relates to relationship strength and consumer loyalty (Park et al, 2010; Thomson et al, 2005). Although emotional brand attachment includes not only affection, but also connection and passion, the latter two are 
not considered here. This is because feelings of connection and passion display higher intensity compared to affection and could not realistically be expected to develop following a single exposure to a brand. Affection, however, can be experienced at the beginning of a relation and is an antecedent of commitment and self-other integration (Fournier, 1998). Willingness to pay is also included as a measure of consumers' reactions to brands as it relates to consumer attitudes (Ward and Dahl, 2014) while offering concrete managerial implications. The following hypotheses regarding a protective effect of brand authenticity in terms of emotional (affection) and behavioural (willingness to pay) consumer responses are examined in this research:

H1: In the presence of a scandal, consumers will express more affection towards an authentic brand (compared to a less authentic brand).

H2: In the presence of a scandal, consumers will be willing to pay more for an authentic brand (compared to a less authentic brand).

Exposure to negative brand information influences consumer responses to the brand (H1 and H2) as well as brand inferences. First, research suggests that consumers judge the responsibility of the brand for a transgression or scandal (Coombs, 2007; Weiner, 1985). Because some scandals emerge from a brand's conscious actions, while others are engendered by incontrollable factors (Hegner et al, 2014), inferences about a brand's responsibility have important consequences in terms of how consumers react to scandals (Folkes 1984; Klein and Dawar, 2004). For example, consumers judge a brand more severely if they believe the brand was intentionally involved in the emergence of the 
scandal, and thus responsible for it (Coombs, 2007). Second, another important brandrelated inference relates to consumers' perception of the brand's hypocrisy. Brand hypocrisy refers to a brand being perceived as hiding material information and pretending to be something that it is not (Wagner et al, 2009). An investigation of perceived hypocrisy in the context of a scandal is appropriate considering that hypocrisy implies a form of dissimulation of one's real nature or one's motivations (Shkalr, 1984), as well as an absence of transparency. Hypocrisy further involves a disconnection between an organization's public image and its real nature or intentions and plays an important role in consumers' evaluations of an organization (Wagner et al, 2009).

Due to the trustworthiness associated with authentic brands and the committed consumer-brand relation that emerges (Morhart et al, 2015), we expect not only a protective effect of brand authenticity on consumers' affective and behavioural responses ( $\mathrm{H} 1$ and $\mathrm{H} 2$ ), but also on brand-related inferences regarding brand responsibility and hypocrisy. In line with this reasoning, consumers may perceive an authentic brand involved in a scandal as less responsible for the scandal and less hypocritical.

H3: In the presence of a scandal, consumers perceive a more (vs. less) authentic brand as less responsible for the scandal.

H4: In the presence of a scandal, consumers perceive a more (vs. less) authentic brand as less hypocritical.

In sum, the relationship literature leads to hypotheses regarding the interactive effect of brand scandals and brand authenticity (i.e., a protective effect of brand authenticity when 
a scandal arises) on emotional and behavioural responses (affection and willingness to pay; $\mathrm{H} 1$ and $\mathrm{H} 2$ ) as well as brand-related inferences (perceived responsibility for the scandal and hypocrisy; $\mathrm{H} 3$ and $\mathrm{H} 4)$.

\section{Method}

\section{Pretests}

The purpose of the first pretest was to establish that the brand authenticity manipulations used in this research resulted in different levels of perceived brand authenticity, but not brand attitude, brand quality, emotional and informational tone of the advertisement, advertisement believability, and appeal. One hundred and fourteen adult consumers ( $60 \%$ female, average age: 51.6 years) recruited from a Canadian panel participated in an online study in September 2014. Participants were randomly assigned to one of two fictitious advertisements for a sports apparel brand, which served as the brand authenticity manipulations. The two advertisements (i.e., more and less authentic brand) were developed in light of prior research that conceptualized brand authenticity along four dimensions: continuity (i.e., a brand's timelessness, historicity, and ability to transcend trends), credibility (i.e., a brand's honesty toward the consumer, and its ability to fulfill its claims), integrity (i.e., a brand's adherence to good values and sincere care for consumers), and symbolism (i.e., a brand's potential to serve as a resource for identity construction by providing self-referential cues; Morhart et al, 2015). The more authentic brand advertisement emphasized each dimension: "We are passionate about our products and care about our customers" (integrity), "Providing sports apparel since 1950" 
(continuity), "High quality sports apparel that reflects who you are" (credibility and symbolism), "The authentic choice you can count on" (credibility). The less authentic brand included the following claims: "High quality sports apparel for all your activities", "We offer our customers a variety of styles, fabrics, and colors", "Providing sports apparel since 2013", and "The athletic choice for your activities". Ad design and amount of information was similar across conditions (see Appendix A).

Participants rated the featured brand as well as the advertisement itself. The measures consisted of brand authenticity ("Please indicate how authentic you perceive the brand LIVA to be," anchored not authentic at all/very authentic), brand attitude (Nan and Heo, 2007), brand quality (Frazier and Lassar, 1996), emotional and informational tone of the advertisement (Jourdan, 1999), advertisement believability, and appeal. All measures in this research consisted of seven-point scales.

The manipulations were successful: Perceived brand authenticity was greater for the more authentic brand $\left(\mathrm{Mean}_{\text {authentic }}=4.49\right.$, Mean $\left._{\text {less authentic }}=3.90, t(112)=1.95, p=.05\right)$. The brands did not differ in terms of brand attitude $\left(\operatorname{Mean}_{\text {authentic }}=4.29\right.$, Mean ${ }_{\text {less authentic }}=$ $3.92, t(112)=1.26, p=.21)$ and brand quality $\left(\mathrm{Mean}_{\text {authentic }}=4.21\right.$, Mean less authentic $=4.03$, $t(112)=.67, p=.50$ ). The nature of the brand (authentic, less authentic) featured in the advertisements did not affect the informational $\left(\operatorname{Mean}_{\text {authentic }}=3.54\right.$, Mean $n_{\text {less authentic }}=$ $3.68, t(112)=-.50, p=.62)$ and emotional tone of the ad $\left(\mathrm{Mean}_{\text {authentic }}=3.81\right.$, Mean $_{\text {less }}$ authentic $=3.67, t(112)=.48, p=.64)$, believability $\left(\operatorname{Mean}_{\text {authentic }}=4.25\right.$, Mean $_{\text {less authentic }}=$ 4.03, $t(112)=.69, p=.50)$, and appeal $\left(\right.$ Mean $_{\text {authentic }}=3.60$, Mean $_{\text {less authentic }}=3.41, t(112)$ $=.58, p=.56)$. 
A second pretest established that the authentic and the less authentic brand featured in the advertisements differed not only in the global level of authenticity, but also in terms of the four brand authenticity dimensions proposed in the literature (Morhart et al, 2015). A sample of 286 students (51\% female, average age: 21.3 years) completed the pretest in exchange for course credit in October 2014. Participants were randomly assigned to one of the two advertisements (more or less authentic brand) and answered questions regarding the brand's perceived continuity (e.g., "This is a timeless brand", $\alpha=.83$ ), credibility (e.g., "This is a brand that accomplishes its value promise", $\alpha=.80$ ), integrity (e.g., "This is a brand that cares about its consumers", $\alpha=.78$ ), and symbolism (e.g., "This is a brand that connects people with what is really important", $\alpha=.83$ ). On all dimensions, perceived brand authenticity was greater for the more authentic brand (continuity: $\operatorname{Mean}_{\text {authentic }}=4.83$, Mean $_{\text {less authentic }}=2.89, t(284)=-13.53, p<.001$; credibility: $\operatorname{Mean}_{\text {authentic }}=4.30$, Mean less authentic $=3.93, t(284)=-2.77, p<.01$; integrity: Mean $_{\text {authentic }}=4.31$, Mean less authentic $=3.64, t(284)=-5.05, p<.001 ;$ symbolism: $\operatorname{Mean}_{\text {authentic }}=4.07$, Mean less authentic $\left.=3.55, t(284)=-3.32, p<.01\right)$. The two pretests confirm that the manipulation of brand authenticity through fictitious advertisements was successful in terms of global and dimension-level brand authenticity, but did not affect other brand-related variables.

\section{Sample, procedure, and measures}

Two hundred twenty-eight adult consumers (60\% female, average age: 49.6 years) recruited from a Canadian consumer panel participated in an online study in November 2014. Participants were randomly assigned to a condition in a 2 (brand: more authentic, 
less authentic $) \times 2$ (scandal: present, absent) between-participants design (57 participants per condition). Participants first viewed one of the two pretested advertisements (i.e., more or less authentic brand) and then read additional information about the brand, which served as the manipulation of scandal (present: "The brand LIVA has always promoted the importance of its workers' rights. However, the brand has recently made headlines because most of LIVA's sports apparel are made in sweatshop factories using child labour and providing poor working conditions;" absent: "The brand LIVA is launching a new advertising campaign. The advertising campaign includes print advertising, television spots and digital executions.”).

Participants then completed measures of affection towards the brand ("Please indicate the extent to which the following word describe your feeling toward the brand:" affectionate, loved; $r=.91$; Malär et al, 2011; Thomson et al, 2005) and willingness to pay for the branded product ("How much would you be willing to pay for the sweater depicted in the ad?" in dollars). The measures also included perceived hypocrisy (e.g., "The brand acts hypocritically," "The brand says and does two different things", anchored strongly disagree/strongly agree; $\alpha=.94$; Wagner et al, 2009) and perceptions of the brand's perceived responsibility for the scandal ("How accountable is the brand for this situation?" anchored not accountable at all/very accountable; "How responsible is the brand for this situation?" anchored not responsible at all/very responsible; $\alpha=.98)$.

Participants then completed the self-brand connection scale (e.g., "I feel a personal connection to this brand,"; $\alpha=.97$; Escalas and Bettman, 2005) as well as manipulation checks for the scandal ("Please indicate how important/relevant/favourable the additional information was in your evaluation of the brand LIVA"), and demographic questions. In 
all but one case, age and gender did not influence dependant variables (all $p \mathrm{~s}>.10$ ) and are thus not discussed further.

\section{Manipulation checks}

The information in the scandal present (vs. absent) condition was perceived as more important $\left(\right.$ Mean $_{\text {scandal }}=5.81$, Mean $\left._{\text {no scandal }}=3.81, t(225)=8.23, p<.001\right)$ and relevant $\left(\operatorname{Mean}_{\text {scandal }}=5.67\right.$, Mean $\left._{\text {no scandal }}=3.74, t(225)=7.95, p<.001\right)$, but less favourable $\left(\operatorname{Mean}_{\text {scandal }}=2.30\right.$, Mean $\left._{\text {no scandal }}=4.37, t(225)=-8.98, p<.001\right)$. The brand authenticity manipulation did not interact with the scandal manipulation to influence these perceptions (all $p s>.20)$.

\section{Results}

Affection. H1 predicts that consumers express more affection towards an authentic (vs. less authentic) brand in the presence of a scandal. An ANOVA with two factors (brand authenticity: authentic/less authentic; scandal: absent/present) and affection as the dependent variable revealed a main effect of brand authenticity $(F(1,224)=6.86, p<$ $.01)$ and a main effect of scandal $(F(1,224)=83.48, p<.001)$. Affection toward the authentic brand was greater $\left(\right.$ Mean $_{\text {authentic }}=3.70$, Mean $_{\text {less authentic }}=3.22, t(236)=-2.07, p$ $<.05)$. Affection was lower in the presence of a scandal $\left(\mathrm{Mean}_{\text {scandal }}=2.54, \mathrm{Mean}_{\text {no scandal }}\right.$ $=4.43, t(226)=9.03, p<.001)$. The interaction between brand authenticity and scandal was not significant $(p=.43)$.

The hypothesis was tested directly through planned comparisons (Winer, 1971). In the absence of a scandal, brand authenticity did not influence affection $\left(\mathrm{Mean}_{\text {authentic }}=4.61\right.$, 
Mean $\left._{\text {less authentic }}=4.25, t(112)=-1.18, p=.24\right)$. In the presence of a scandal, however, participants expressed more affection towards the authentic brand $\left(\mathrm{Mean}_{\text {authentic }}=2.90\right.$, Mean $\left._{\text {less authentic }}=2.18, t(112)=-2.59, p<.05\right)$. In support of H1, this result suggests that brand authenticity results in a protective effect in the case of a scandal. In addition, although a scandal resulted in a decrease in affection that was smaller for the authentic (vs. less authentic) brand, the authentic brand was nonetheless hurt by the occurrence of a scandal (authentic brand: $\mathrm{Mean}_{\text {no scandal }}=4.61$, Mean $_{\text {scandal }}=2.90, t(112)=5.95, p<.001$; less authentic brand: $\operatorname{Mean}_{\text {no scandal }}=4.25$, Mean $\left._{\text {scandal }}=2.18, t(112)=6.96, p<.001\right)$.

Willingness to pay. $\mathrm{H} 2$ predicts that consumers are willing to pay more for the authentic (vs. less authentic) brand in the presence of a scandal. An ANOVA with two factors (brand authenticity: authentic/less authentic; scandal: absent/present) and willingness to pay as the dependent variable revealed a main effect of scandal $(F(1,224)$ $=27.65, p<.001)$. Willingness to pay was lower in the presence of a scandal $\left(\right.$ Mean $_{\text {scandal }}$ $=13.18$, Mean $\left._{\text {no scandal }}=24.57, t(226)=5.25, p<.001\right)$. The main effect of brand authenticity and brand authenticity $\times$ scandal interaction were not significant $(p s>.22)$.

The hypothesis was tested through planned comparisons (Winer, 1971). In the absence of a scandal, willingness to pay did not differ across brand authenticity levels $\left(\mathrm{Mean}_{\text {authentic }}=24.17, \mathrm{Mean}_{\text {less authentic }}=24.98, t(112)=.23, p=.82\right)$. The findings indicate that in the presence of a scandal, willingness to pay is greater for the authentic brand $\left(\mathrm{Mean}_{\text {authentic }}=15.53, \mathrm{Mean}_{\text {less authentic }}=10.82, t(112)=-1.94, p=.056\right)$. This result is indicative of a protective effect of brand authenticity and supports H2. It is also consistent with consumers' affective reactions toward the brand (H1). Authentic brands are nonetheless hurt by the presence (vs. absence) of a scandal (authentic brand: Mean ${ }_{n o}$ 
$\operatorname{scandal}=24.17$, Mean $_{\text {scandal }}=15.53, t(112)=3.02, p<.01$; less authentic brand: Mean $_{\text {no }}$ scandal $=24.98$, Mean $\left._{\text {scandal }}=10.82, t(112)=4.35, p<.001\right)$.

Overall, these results indicate that higher levels of brand authenticity afford brands a certain level of protection: When a scandal occurred, consumers expressed more affection and willingness to pay more for the authentic (vs. less authentic) brand. Authentic brands are adversely affected by a scandal, as both affection and willingness to pay decreased for the authentic brand in the scandal condition. However, consistent with the hypotheses, when a scandal occurred, consumers responded more positively to the authentic brand than the less authentic brand, a difference that did not emerge in the no scandal condition. Figure 1 summarizes these findings. The remaining hypothesis tests ( $\mathrm{H} 3$ and $\mathrm{H} 4)$ focus on the effect on specific brand-related inferences, responsibility for the scandal and hypocrisy.

Insert Figure 1 about here

Brand responsibility. H3 predicts that consumers perceive the authentic (vs. less authentic) brand as less responsible for the scandal. An ANOVA with two factors (brand authenticity: authentic/less authentic; scandal: absent/present) and perceived responsibility of the brand for the scandal as the dependent variable revealed a significant two-way interaction $(F(1,224)=9.67, p<.01)$. The main effects of brand authenticity and scandal were not significant ( $p$ s $>.09)$. In the absence of a scandal, brand responsibility did not differ across brand authenticity conditions $\left(\right.$ Mean $_{\text {authentic }}=4.54$, Meanless authentic $=4.21, t(112)=-1.07, p=.29)$. In the presence of a scandal, perceptions 
of brand responsibility for the scandal were lower for the authentic brand $\left(\mathrm{Mean}_{\text {authentic }}=\right.$ 3.27, Mean $\left._{\text {less authentic }}=4.51, t(112)=3.10, p<.01\right)$. H3 was supported.

Brand hypocrisy. $\mathrm{H} 4$ proposes that consumers perceive the authentic brand as less hypocritical than the less authentic brand. An ANOVA with two factors (brand authenticity: authentic/less authentic; scandal: absent/present) and hypocrisy as the dependent variable indicated a significant main effect of scandal $(F(1,224)=181.17, p<$ $.001)$ and an interaction effect of scandal and brand authenticity $(F(1,224)=6.11, p<$ $.05)$. Perceived hypocrisy of the brand was greater when a scandal occurred $\left(\mathrm{Mean}_{\text {scandal }}=\right.$ 2.74, Mean $\left._{\text {noscandal }}=5.54, t(226)=-13.31, p<.001\right)$. The interaction pattern indicated that in the absence of a scandal, perceived hypocrisy did not differ across brand authenticity conditions $\left(\right.$ Mean $_{\text {authentic }}=2.88$, Mean $_{\text {less authentic }}=2.59, t(112)=-1.01, p=$ .32). In the presence of a scandal, lower levels of perceived hypocrisy were associated with the authentic brand $\left(\mathrm{Mean}_{\text {authentic }}=5.17\right.$, Mean $_{\text {less authentic }}=5.91, t(112)=2.48, p<$ .05). These findings support $\mathrm{H} 4$.

These results suggest that brand authenticity has a protective effect in terms of brandrelated inferences if a scandal occurs. An authentic (vs. less authentic) brand involved in a scandal is considered less responsible for it and is viewed as less hypocritical. Figure 2 illustrates these findings. Overall, all hypotheses $(\mathrm{H} 1, \mathrm{H} 2, \mathrm{H} 3, \mathrm{H} 4)$ were supported.

Insert Figure 2 about here

Additional analyses: Mediation effects. Considering the significant influence of brand authenticity on willingness to pay, affection, perceived hypocrisy, and perceived 
responsibility in the presence of a scandal, additional analyses were conducted to provide initial insights regarding the psychological process underlying the effects of brand authenticity. Consistent with the theory of planned behaviour, which suggests that attitudes (either affective or cognitive) precede intentions and behaviours (Ajzen, 1991), and considering that willingness to pay is a concrete indicator of consumers' behavioural intentions (Ajzen and Driver, 1992; Hultman et al, 2015), the mediating role of affection, hypocrisy and responsibility with regard to consumers' willingness to pay was explored.

First, a mediation analysis was conducted to examine whether brand affection acted as a mediator between brand authenticity and consumers' willingness to pay in the scandal present condition (PROCESS Model 4; Hayes, 2013). Consistent with full mediation, the more (vs. less) authentic brand was associated with higher willingness to pay ( $\beta=4.79$, $t(114)=1.94, p=.05)$ and enhanced affection felt towards the brand $(\beta=.72$, $t(114)=2.59, p<.05)$. Controlling for brand authenticity, affection predicted willingness to pay $(\beta=3.92, t(114)=5.28, p<.001)$, whereas the coefficient for brand authenticity became nonsignificant ( $p>.40$; Sobel's $Z=2.29, p<.05)$.

Second, perceived hypocrisy mediated the effect of brand authenticity on consumers' willingness to pay when a scandal occurred. A more (vs. less) authentic brand led to higher willingness to pay $(\beta=4.79, t(114)=1.94, p=.05)$ and lower levels of perceived hypocrisy $(\beta=-.74, t(114)=-2.47, p<.05)$. When controlling for brand authenticity, perceived hypocrisy predicted willingness to pay $(\beta=-2.29, t(114)=-3.15, p<.001)$, whereas the coefficient for brand authenticity became nonsignificant $(p>.21$; Sobel's $Z=1.87, p=.06)$. 
Third, perceived responsibility did not mediate the effect of brand authenticity on willingness to pay (i.e., no significant indirect effects; Sobel test $Z=-1.43, p=.15$ ). In sum, these analyses provide initial evidence for the mediating roles of affection and hypocrisy in understanding consumers' behavioural reactions to a more (vs. less) authentic brand involved in a scandal.

Additional analyses: Brand connection. This research proposed that higher levels of commitment induced by authentic brands explain the protective effect of brand authenticity. This is consistent with previous work highlighting that brand commitment plays a critical role in inducing consumer resistance to negative information about the brand (Aaker et al, 2004; Ahluwalia et al, 2000; Ahluwalia et al, 2001). To examine this possibility, consumers' self-brand connection with the authentic (vs. less authentic) brand was examined in the scandal absent condition. Consumers expressed directionally higher levels of self-brand connection with the authentic brand compared to the less authentic brand $\left(\right.$ Mean $_{\text {authentic }}=3.49$, Mean $\left._{\text {less authentic }}=2.99, t(112)=-1.55, p=.11\right)$. Although this result does not provide strong support of the commitment hypothesis and must be interpreted with caution, it is important to acknowledge that it is difficult to induce strong connections following a single exposure to a fictitious brand, given that such connections usually develop over time (Thomson et al, 2005). This is discussed in the limitations section.

Alternative explanations: Brand age. Results suggest that brand authenticity has a protective effect when a scandal occurs. In the experiment, brand authenticity was manipulated globally using cues related to the four dimensions (continuity, credibility, integrity, symbolism; Morhart et al, 2015). It is thus argued that the overall authentic 
brand image created in consumers' minds is responsible for the protective effect. An alternative explanation is plausible considering the operationalization of continuity through brand age used in the study (i.e., "1950" vs. "2013"). It is possible that consumers reacted more negatively towards the less authentic brand specifically because it is a young brand already involved in a scandal. An experiment was conducted to rule out this possibility.

Two hundred adult consumers (56\% female, average age: 47.4 years) from a Canadian consumer panel participated in an online study. Participants were randomly assigned to a condition in a 2 (brand age: old, young) $\times 2$ (scandal: present, absent) betweenparticipants design. Participants viewed one of the two advertisements differing only in terms of brand age (old: "Since 1950"; young: "Since 2015"). The other elements presented in the ads did not relate to authenticity dimensions (see Appendix B). Participants were then exposed to the scandal manipulation, which replicated the main study. Participants completed the same measures (i.e., affection, hypocrisy, etc.) and, additionally, reported their anger towards the brand (e.g., "I am angry at this brand"; $\alpha=$ .98; Bonifield and Cole, 2007). The study ended with manipulation checks for brand age (continuity; $\alpha=.97$; Morhart et al, 2015) and for the scandal manipulations.

Manipulation checks were successful. Perceived continuity was greater for the old versus the young brand $\left(\mathrm{Mean}_{\text {old }}=4.32\right.$, Mean $\left._{\text {young }}=3.03, t(198)=5.23, p<.001\right)$. The scandal manipulation did not interact with the age manipulation (all $p \mathrm{~s}>.37$ ). The information in the scandal condition was perceived as more important $\left(\mathrm{Mean}_{\text {scandal }}=5.05\right.$, Mean $\left._{\text {noscandal }}=3.47, t(198)=-5.77, p<.001\right)$ and relevant $\left(\operatorname{Mean}_{\text {scandal }}=4.96\right.$, Mean $\left._{\text {noscandal }}=3.60, t(198)=-4.94, p<.001\right)$, but marginally less favorable $\left(\right.$ Mean $_{\text {scandal }}=$ 
3.33, Mean $\left._{\text {noscandal }}=3.79, t(198)=1.65, p=.10\right)$ than in the no scandal condition. The age manipulation did not interact with the scandal manipulation (all $p \mathrm{~s}>.38$ ).

Results rule out the influence of brand age for all variables. First, an ANOVA with affection as the dependent variable revealed a main effect of scandal $\left(\right.$ Mean $_{\text {scandal }}=2.93$, Mean $\left._{\text {no scandal }}=3.49, t(198)=2.22, p<.05\right)$ and other non-significant effects $(p \mathrm{~s}>.23)$. In the absence of a scandal, brand age did not influence affection $\left(\right.$ Mean $_{\text {old }}=3.62$, Mean $_{\text {young }}$ $=3.36, t(98)=.77, p=.44)$. In the presence of a scandal, similarly, brand age did not influence affection $\left(\mathrm{Mean}_{\mathrm{old}}=2.75\right.$, Mean $\left._{\mathrm{young}}=3.10, t(98)=-.92, p=.36\right)$. Second, an ANOVA with willingness to pay as the dependent variable revealed a main effect of scandal $\left(\mathrm{Mean}_{\text {scandal }}=21.80, \mathrm{Mean}_{\text {no scandal }}=32.75, t(191)=2.96, p<.01, p<.01\right)$ and other non-significant effects $(p s>.24)$. Brand age did not influence willingness to pay in the no scandal $\left(\mathrm{Mean}_{\mathrm{old}}=31.51, \mathrm{Mean}_{\mathrm{young}}=33.96, t(93)=-.41, p=.68\right)$ nor in the scandal $\left(\right.$ Mean $_{\text {old }}=18.70$, Mean $\left._{\text {young }}=24.90, t(96)=-1.42, p=.16\right)$ conditions. Third, an ANOVA with responsibility as the dependent variable revealed a main effect of scandal $\left(\right.$ Mean $_{\text {scandal }}=5.29$, Mean $\left._{\text {no scandal }}=4.76, t(198)=-2.14, p<.05\right)$ and other non-significant effects $(p s>.23)$. Brand age did not influence perceived responsibility, whether when a scandal occurred $\left(\mathrm{Mean}_{\mathrm{old}}=5.17, \mathrm{Mean}_{\mathrm{young}}=5.40, t(98)=-.60, p=.55\right)$ or not $\left(\mathrm{Mean}_{\text {old }}\right.$ $=4.94$, Mean $\left._{\text {young }}=4.58, t(98)=1.16, p=.25\right)$. Fourth, an ANOVA with hypocrisy as the dependent variable revealed a main effect of scandal (Hypocrisy: Mean $_{\text {scandal }}=4.41$, Mean $\left._{\text {no scandal }}=3.09, t(198)=-5.03, p<.001\right)$ and other non-significant effects $(p \mathrm{~s}>.14)$. Brand age did not influence hypocrisy in the absence $\left(\operatorname{Mean}_{\text {old }}=2.83\right.$, Mean $_{\text {young }}=3.35$, $t(98)=-1.62, p=.11)$ or presence of a scandal $\left(\right.$ Mean $_{\text {old }}=4.28$, Mean $_{\text {young }}=4.54, t(98)=$ $-.63, p=.53)$. Fifth, an ANOVA with anger as the dependent variable revealed a main 
effect of scandal (Anger: Mean $_{\text {scandal }}=4.23$, Mean $\left._{\text {no scandal }}=2.26, t(198)=-7.20, p<.001\right)$ and other non-significant effects $(p s>.10)$. Anger was not influenced by the age of the brand, regardless of the presence $\left(\right.$ Mean $_{\text {old }}=4.51$, Mean $_{\text {young }}=3.94, t(98)=-1.36, p=$ $.18)$ or absence of scandal $\left(\mathrm{Mean}_{\text {old }}=2.08\right.$, Mean $\left._{\text {young }}=2.45, t(98)=-1.07, p=.29\right)$. These results indicate that brand age is not responsible for the effects obtained in the study and strenghten the role of an overall authenticity perception in understanding consumers' reactions following the scancal.

\section{Discussion}

This article examined to what extent brand authenticity influences consumer responses when a brand is involved in a scandal. Results support that an authentic brand image alleviates negative consequences of a brand scandal in terms of affection, willingness to pay, perceived brand responsibility for the scandal, and perceived hypocrisy. In the presence of a scandal, consumers evaluated the authentic (vs. less authentic) brand more positively in terms of emotional responses (higher affection), behavioural intentions (higher willingness to pay), and brand-related perceptions (lower perceived responsibility for the scandal and lower perceived hypocrisy). It is important to note, however, that the authentic brand was nonetheless negatively affected by a scandal (compared to a no scandal condition). Further, additional analyses show that affection and perceived hypocrisy mediate the impact of brand authenticity on consumers' willingness to pay in the context of a scandal.

\section{Theoretical contributions}


This research contributes to the literature in several ways. First, it offers new insights regarding the consequences of brand authenticity. Previous work investigated the nature of authenticity (Leigh et al, 2006; Napoli et al, 2014), its consequences (Eggers et al, 2013; Guèvremont and Grohmann, 2016), and consumers' search for and negotiation of authenticity in consumption experiences (Beverland and Farrelly, 2010; Rose and Wood, 2005). Little research has been directed toward a better understanding brand authenticity effects when brands face difficult times. Considering the nature of brand authenticity and the expectations of transparency it elicits (Gilmore and Pine, 2007), such an examination is of great interest. This research shows that brand authenticity protects brands from consumer reactions to negative brand-related information. Whereas prior research focused on attitudes, purchase intentions or emotional brand attachment (e.g., Guèvremont and Grohmann, 2016; Napoli et al, 2014), this article examines affective (i.e., affection) and behavioural (i.e., willingness to pay) consumer responses as well as brand-related inferences (i.e., perceived responsibility, hypocrisy). In addition, this research provides initial evidence of mediation, such that affection and hypocrisy function as mediators in shaping consumers' behavioural reactions when more (vs. less) authentic brands are involved in a scandal. The results of this mediation analysis also highlight the importance of hypocrisy in driving consumers' perceptions of brands and firms (Wagner et al, 2009). Whereas research on hypocrisy focused on human relations (Batson et al, 2002; Shklar, 1984), this article shows that hypocrisy is relevant in a consumer-brand relationship context and answers Wagner and colleagues' (2009) call for future work in that area.

Second, this article contributes to the literature on brand scandals by investigating the 
influence of an authentic brand image on consumer reactions to an ethical scandal. Although research pertaining to brand scandals is extensive, most focused on productrelated (e.g., Klein and Dawar, 2004; Laufer and Coombs, 2006) rather than ethical scandals. However, as consumers demand more transparency and consistency between brand commitments and actions (Eggers et al, 2013), it is important to examine transgressions related to ethical issues. Moreover, the brand scandal literature identifies several moderators, such as self-relevance of the issue involved in an ethical scandal (Trump, 2014) or brand actions following a scandal (Dutta and Pullig, 2011). This article demonstrates that an authentic brand image is instrumental in reducing the detrimental consequences associated with an ethical scandal. Relatedly, previous work finds a protective effect of a favourable corporate reputation, whereas this article focuses on the effects of an authentic brand image created by brand communication (Beverland et al, 2008). An authentic brand image is built around brand continuity, credibility, integrity, and symbolism as perceived by consumers (Morhart et al, 2015) and differs from corporate reputation, a value judgment about an organization's qualities based on its past actions, decisions, and financial history (Balmer, 1998). Compared to corporate reputation, brand image is more malleable, and can be influenced by brand communication (Bennett and Gabriel, 2003).

Third, the finding that authentic brands benefit from protection against the negative consequences of scandals contributes to the understanding of authentic brands from a consumer-brand relationship perspective (Fournier, 1998). The findings are consistent with the literature regarding the positive effects of commitment on consumer reactions to negative brand information (Aaker et al, 2004; Ahluwalia et al, 2000). Although the 
effect of authentic brand on brand-self connections - which are indicative of greater commitment to consumers' relationship with a brand — were only directionally consistent with expectations, other positive responses associated with higher brand commitment were observed in terms of affective, behavioural, and brand-related inferences. This suggests that authentic brands indeed elicit relatively strong connections with consumers, in line with the existential perspective on authenticity (Arnould and Price, 2000; Beverland and Farrelly, 2010). In addition, evidence of the protective effect of brand authenticity eliminates an alternative theoretical prediction regarding brand authenticity's role in a scandals context: It is possible that high levels of brand authenticity backfire when a brand scandal occurs. The disconfirmation of expectations framework suggests that authentic brands may be particularly vulnerable to brand transgressions. Considering that authentic brands promote an image of trust (Napoli et al, 2014), the involvement of such brands in a scandal may interfere with consumer expectations and aggravate their responses, a finding that has been observed in the corporate reputation literature (Sohn and Lariscy, 2004). This article finds support for a commitment based rather than expectancy disconfirmation explanation.

\section{Managerial contributions}

From a managerial perspective, it is essential for brands to be consistent with their image and values (Eggers et al, 2013) and to avoid brand scandals. However, reality is that scandals inevitably occur and have detrimental consequences (Coombs, 2007; Huber et $a l, 2010)$. In the event of a scandal, this article finds that consumers show more clemency toward a brand that is perceived as authentic. Some real-life cases support this 
proposition. For example, a few years ago, the brand Maple Leaf was involved in a crisis - the outbreak of the listeria bacteria in its packaged meat products causing several deaths (CBC News, 2008). Despite the severity of the crisis, the brand recovered quickly from the situation and did not lost consumer confidence (Owram, 2009; Tattri, 2009). Although many factors contributed to this recovery—including the brand's transparency in responding to the situation-, it is plausible that Maple Leaf's image of authenticity (i.e., its Canadian image rooted in history, tradition, family, and sustainable valuesfactors contributing to a brand's authenticity; Beverland, 2006) helped soften consumers' reactions. For a brand manager, this means that it is important to consider brand image carefully and — where appropriate — highlight the brand's authenticity. In the event of a scandal, as revealed in this study, such as positioning might have a non-negligible protective effect compared to a less authentic brand. Concretely, this can be achieved by focusing on one or more of the brand authenticity dimensions identified in past work (i.e., continuity, credibility, integrity, symbolism; Morhart et al, 2015). Here are some examples. A longstanding brand could emphasize its founding date or its connection to past to signal continuity (Beverland et al, 2008), such as Stella Artois' line "since 1366". A reputable brand could highlight its quality standards to communicate its credibility (Beverland, 2006). Victorinox, for example, emphasizes in its advertisements that its Swiss Army knife "sets the standards". A brand could further emphasize its integrity by promoting its social involvement, as done by Whole Foods who communicates its local initiatives and donations to charities (McNew, 2015). A symbolic brand could accentuate its human image to increase its potential to connect with consumers' identity (Morhart et al, 2015), for example Apple and its trendy, cool, and young brand image. Other ways to 
signal authenticity include — but are not limited to — designing a image rooted in tradition (Beverland, 2006), emphasizing the excellence and superiority of the brand (Napoli et al, 2014), communicating values consumers care for (Morhart et al, 2015), and acting upon its word (Eggers et al 2013). Managers should however note that consumers are careful interpreters of marketing cues related to brand authenticity (Brown et al, 2003) and are increasingly sceptical towards advertisement in general (Obermiller and Spangenberg, 1998). Thus, communicating brand authenticity must be approached as a reflection of the identity of the brand, in the sense that it should reflect what the brand really stands for (Nadan, 2005). With that in mind, managers can induce stronger connections with consumers (Morhart et al, 2015) and protect their brand against negative brand-related information, as suggested in this research.

\section{Limitations and future research}

Several limitations need to be acknowledged. First, this research focused on an experimental manipulation of the presence versus absence of an ethical scandal. It is important to consider other types of scandals. Product-related scandals would be particularly interesting considering the credibility associated with authentic brands (Morhart et al, 2015). Moreover, the impact of scandal severity is an important consideration in future work. Finally, the degree of responsibility of the brand in bringing about the scandal is worth examining. Because intentional harm caused by a crisis is more likely to generate negative responses (Hegner et al, 2014), it is worth investigating whether an authentic brand would experience a greater level of backlash once it is perceived as highly responsible for a scandal. 
Second, this article proposes that authentic brands benefit from a protective effect based on higher levels of consumer commitment to such brands, in line with the literature on the impact of brand commitment on consumer resistance to negative brand information (Aaker et al, 2004). Support for a commitment based mechanism was only directional, however, in that consumers expressed somewhat higher levels of self-brand connection with the more (vs. less) authentic brand. Future research should address this issue. It is possible that committed consumers develop counterarguments when exposed to negative information. Examining the mediating role of consumers' thoughts following the exposure to a scandal (Ahluwalia et al, 2000) could be a insightful in documenting the role of commitment. Alternatively, consumer commitment to the brand could be assessed by means of measures other than self-brand connections. Brand trust, for example, might be a valuable indicator of commitment to authentic brands. Trust is rooted in a relationship perspective and is defined as a sense of security consumers feel when interacing with the brand (Delgado-Ballester et al, 2003). Because an image of authenticity can increase brand trust (Eggers et al, 2013), further contributing to consumer commitment (Delgado-Ballester et al, 2003), this idea is promising. Lastly, stronger evidence for a commitment based mechanism for the protective effects of brand authenticity may arise in studies that go beyond a single exposure to a target brand. It is likely that the current research context (i.e., single online exposure to a fictitious brand) precluded consumers from developing a committed relationship with the authentic brand. Future work could alleviate this concern in longitudinal studies or by including real brands. Such an approach would also entail a greater degree of external validity. 
Lastly, the conclusions and contributions of this article are based on a single study, and thus need to be interpreted with caution. Replications involving real brands and alternative manipulations of brand authenticity would considerably strengthen the evidence regarding a protective effect of brand authenticity. In this research, brand authenticity was experimentally manipulated in advertisements — consistent with prior work (Morhart et al, 2015) that adopts a constructivist perspective on authenticity (Leigh et al, 2006). Although the manipulations were successful, it is important to identify how many and what kind of claims are sufficient, yet effective in evoking an intended brand authenticity level. Such an examination requires more research. 


\section{References}

Aaker, J., Fournier, S. and Brasel, S.A. (2004) When good brands do bad. Journal of Consumer Research 31(1): 1-16.

Ahluwalia, R., Burnkrant, R.E. and Unnava, H.R. (2000) Consumer response to negative publicity: The moderating role of commitment. Journal of Marketing Research 37(2): 203-214.

Ahluwalia, R., Unnava, H.R. and Burnkrant, R.E. (2001) The moderating role of commitment on the spillover effect of marketing communications. Journal of Marketing Research 38(4): 458-470.

Alexander, N. (2009) Brand authentication: Creating and maintaining brand auras. European Journal of Marketing 43(3/4): 551-562.

Arnould, E.J. and Price, L.L. (2000) Authenticating acts and authoritative performances: Questing for self and community. In: S. Ratneswar, D. Glenick and C. Huffman (eds.) The Why of Consumption: Contemporary Perspectives on Consumer Motives. New York: Routledge: 140-163.

Ajzen, I. (1991) The theory of planned behavior. Organizational Behavior and Human Decision Processes 50(2): 179-211.

Ajzen, I., and Driver, B. L. (1992) Contingent value measurement: On the nature and meaning of willingness to pay. Journal of Consumer Psychology 1(4): 297-316.

Barnett, M. L., Jermier, J. M. and Lafferty, B. A. (2006) Corporate reputation: The definitional landscape. Corporate Reputation Review 9(1): 26-38.

Batson, C. D., Thompson, E. R. and Chen, H. (2002) Moral hypocrisy: Addressing some alternatives. Journal of Personality and Social Psychology 83(2): 330-340. 
Bennett, R., and Gabriel, H. (2003) Image and reputational characteristics of UK charitable organizations: An empirical study. Corporate Reputation Review 6(3): 276-289.

Beverland, M. (2006) The 'real thing': Branding authenticity in the luxury wine trade. Journal of Business Research 59(2): 251-258.

Beverland, M.B. and Farrelly, F.J. (2010) The quest for authenticity in consumption: Consumers' purposive choice of authentic cues to shape experienced outcomes. Journal of Consumer Research 36(5): 838-856.

Beverland, M.B., Lindgreen, A. and Vink, M.W. (2008) Projecting authenticity through advertising: Consumer judgments of advertisers' claims. Journal of Advertising 37(1): 5-15.

Black, E. L., Carnes, T. A., and Richardson, V. J. (2000) The market valuation of corporate reputation. Corporate Reputation Review 3(1): 31-42.

Bonifield, C., and Cole, C. (2007) Affective responses to service failure: Anger, regret, and retaliatory versus conciliatory responses. Marketing Letters, 18(1-2): 85-99.

Brady, A. (2003) How to generate sustainable brand value from responsibility. Journal of Brand Management 10(4): 279-289.

Brown, T. J., and Dacin, P. A. (1997) The company and the product: Corporate associations and consumer product responses. The Journal of Marketing (61)1: $68-84$.

Brown, S., Kozinets, R.V. and Sherry Jr, J.F. (2003) Teaching old brands new tricks: Retro branding and the revival of brand meaning. Journal of Marketing 67(3): 1933. 
Brunk, K. H. (2012) Un/ethical company and brand perceptions: Conceptualising and operationalising consumer meanings. Journal of Business Ethics 111(4): 551-565.

CBC News (2008) Listeriosis outbreak timeline. August 26.

http://www.cbc.ca/news/listeriosis-outbreak-timeline-1.694467, accessed November 16, 2016.

Chronis, A. and Hampton, R.D. (2008) Consuming the authentic Gettysburg: How a tourist landscape becomes an authentic experience. Journal of Consumer Behaviour 7(2): 111-126.

Cleeren, K., Dekimpe, M. G., and Helsen, K. (2008) Weathering product-harm crises. Journal of the Academy of Marketing Science 36(2): 262-270.

Cleeren, K., Van Heerde, H.J. and Dekimpe, M.G. (2013) Rising from the ashes: How brands and categories can overcome product-harm crises. Journal of Marketing 77(2): 58-77.

Cohen, E. (1988) Authenticity and commoditization in tourism. Annals of Tourism Research 15(3): 371-386.

Coombs, W.T. (2007) Protecting organization reputations during a crisis: The development and application of situational crisis communication theory. Corporate Reputation Review 10(3): 163-176.

Coombs, W. T. and Holladay, S. J. (2006) Unpacking the halo effect: Reputation and crisis management. Journal of Communication Management 10(2): 123-137.

Dawar, N. and Lei, J. (2009) Brand crises: The roles of brand familiarity and crisis relevance in determining the impact on brand evaluations. Journal of Business Research 62(4): 509-516. 
Dawar, N. and Pillutla, M.M. (2000) Impact of product-harm crises on brand equity: The moderating role of consumer expectations. Journal of Marketing Research 37(2): 215-226.

Dean, D. H. (2004) Consumer reaction to negative publicity effects of corporate reputation, response, and responsibility for a crisis event. Journal of Business Communication 41(2): 192-211.

De Chernatony, L. (1999). Brand management through narrowing the gap between brand identity and brand reputation. Journal of Marketing Management 15(1-3): 157179.

Delgado-Ballester, E., Munuera-Aleman, J. L. and Yague-Guillen, M. J. (2003).

Development and validation of a brand trust scale International Journal of Market Research 45(1): 35-54.

Dutta, S. and Pullig, C. (2011) Effectiveness of corporate responses to brand crises: The role of crisis type and response strategies. Journal of Business Research 64(12): 1281-1287.

Eggers, F., O’Dwyer, M., Kraus, S., Vallaster, C. and Güldenberg, S. (2013) The impact of brand authenticity on brand trust and SME growth: A CEO perspective. Journal of World Business 48(3): 340-348.

Ellen, P. S., Webb, D. J., and Mohr, L. A. (2006). Building corporate associations: Consumer attributions for corporate socially responsible programs. Journal of the Academy of Marketing Science, 34(2), 147-157.

Escalas, J.E. and Bettman, J.R. (2005) Self-construal, reference groups, and brand meaning. Journal of Consumer Research 32(3): 378-389. 
Fine, G.A. (2003) Crafting authenticity: The validation of identity in self-taught art. Theory and Society 32(2): 153-180.

Folkes, V.S. (1984) Consumer reactions to product failure: An attributional approach. Journal of Consumer Research 16(2): 398-409.

Fombrun, C. and Shanley, M. (1990) What's in a name? Reputation building and corporate strategy. Academy of Management Journal 33(2): 233-258.

Fombrun, C. J. and Van Riel, C. B. (2004) Fame \& Fortune: How Successful Companies Build Winning Reputations. New York: Financial Times Prentice Hall books.

Fournier, S. (1998) Consumers and their brands: Developing relationship theory in consumer research. Journal of Consumer Research 24(4): 343-353.

Frazier, G.L. and Lassar, W.M. (1996) Determinants of distribution intensity. Journal of Marketing 60(4): 39-51.

Ghodeswar, B. M. (2008) Building brand identity in competitive markets: A conceptual model. Journal of Product \& Brand Management 17(1): 4-12.

Gilmore, J.H. and Pine, B.J. (2007) Authenticity: What Consumers Really Want. New York: Harvard Business Press.

Gotsi, M. and Wilson, A.M. (2001) Corporate reputation: Seeking a definition. Corporate Communications 6: 24-30.

Grayson, K. and Martinec, R. (2004) Consumer perceptions of iconicity and indexicality and their influence on assessments of authentic market offerings. Journal of Consumer Research 31(2): 296-312.

Guèvremont, A. and Grohmann B (2016) The brand authenticity effect: Situational and individual-level moderators. European Journal of Marketing 50(3/4): 602-620. 
Gundlach, H. and Neville, B. (2012) Authenticity: Further theoretical and practical development. Journal of Brand Management 19(6): 484-499.

Hayes, A. F. (2013) Introduction to Mediation, Moderation, and Conditional Process Analysis: A Regression-Based Approach. New York: Guilford Press.

Hegner, S.M., Beldad, A.D. and Heghuis, S.K. (2014) How company responses and trusting relationships protect brand equity in times of crises. Journal of Brand Management 21(5): 429-445.

Holt, D.B. (2002) Why do brands cause trouble? A dialectical theory of consumer culture and branding. Journal of Consumer Research 29(1): 70-90.

Huber, F., Vollhardt, K., Matthes, I. and Vogel, J. (2010) Brand misconduct: Consequences on consumer-brand relationships. Journal of Business Research 63(11): 1113-1120.

Huber, F., Meyer, F., Vogel, J. and Vollmann, S. (2011) Corporate social performance as antecedent of consumer's brand perception. Journal of Brand Management 19(3): 228-240.

Hultman, M., Kazeminia, A. and Ghasemi, V. (2015) Intention to visit and willingness to pay premium for ecotourism: The impact of attitude, materialism, and motivation. Journal of Business Research, 68(9): 1854-1861.

Ilicic, J. and Webster, C.M. (2014) Investigating consumer-brand relational authenticity. Journal of Brand Management 21(4): 342-363.

Jourdan, P. (1999) Creation and validation of an advertising scale based on the individual perception of the emotional or informational intent of the advertisement. Advances in Consumer Research 26(1): 504-512. 
Keller, K.L. (1993) Conceptualizing, measuring, and managing customer-based brand equity. Journal of Marketing 57(1): 1-22.

Klein, J. and Dawar, N. (2004) Corporate social responsibility and consumers' attributions and brand evaluations in a product-harm crisis. International Journal of Research in Marketing 21(3): 203-217.

Laufer, D. and Coombs, W.T. (2006) How should a company respond to a product harm crisis? The role of corporate reputation and consumer-based cues. Business Horizons 49(5): 379-385.

Laufer, D., Gillespie, K. and Silvera, D. H. (2009) The role of country of manufacture in consumers' attributions of blame in an ambiguous product-harm crisis. Journal of International Consumer Marketing, 21(3): 189-201.

Leigh, T.W., Peters, C. and Shelton, J. (2006) The consumer quest for authenticity: The multiplicity of meanings within the MG subculture of consumption. Journal of the Academy of Marketing Science 34(4): 481-493.

Malär, L., Krohmer, H., Hoyer, W.D. and Nyffenegger, B. (2011) Emotional brand attachment and brand personality: The relative importance of the actual and the ideal self. Journal of Marketing 75(4): 35-52.

McGuire, J., Sundgren, A. and Schneeweiss, T. (1988) Corporate social responsibility and firm financial performance. Academy of Management Journal 31: 854-872.

McNew, S. (2015) Just How Charitable is Whole Foods Inc.?. The Motley Fool, http://www.fool.com/investing/general/2015/07/16/just-how-charitable-is-wholefoods-inc.aspx, accessed November 16, 2016. 
Morhart, F., Malär, L., Guèvremont, A., Girardin, F. and Grohmann, B. (2015) Brand authenticity: An integrative framework and measurement scale. Journal of Consumer Psychology 25(2): 200-218.

Nan, X. and Heo, K. (2007) Consumer responses to corporate social responsibility (CSR) initiatives: Examining the role of brand-cause fit in cause-related marketing. Journal of Advertising 36(2): 63-74.

Nandan, S. (2005) An exploration of the brand identity-brand image linkage: A communications perspective. The Journal of Brand Management 12(4): 264-278.

Napoli, J., Dickinson, S.J., Beverland, M.B. and Farrelly, F. (2014) Measuring consumerbased brand authenticity. Journal of Business Research, 67(6): 1090-1098.

Obermiller, C. and Spangenberg, E. R. (1998) Development of a scale to measure consumer skepticism toward advertising. Journal of Consumer Psychology 7(2): 159-186.

Owram, K. (2009) Maple Leaf Foods recovers from listeria crisis. Thestar.com, October 28,https://www.thestar.com/business/2009/10/28/maple_leaf_foods_recovers_fro

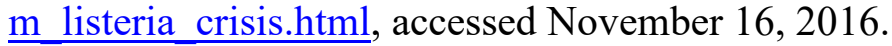

Park, C.W., MacInnis, D.J., Priester, J., Eisingerich, A.B. and Iacobucci, D. (2010) Brand attachment and brand attitude strength: Conceptual and empirical differentiation of two critical brand equity drivers. Journal of Marketing 74(6), 1-17.

Pullig, C., Netemeyer, R.G. and Biswas, A. (2006) Attitude basis, certainty, and challenge alignment: A case of negative brand publicity. Journal of the Academy of Marketing Science 34(4): 528-542. 
Puzakova, M., Kwak, H. and Rocereto, J. F. (2013) When humanizing brands goes wrong: the detrimental effect of brand anthropomorphization amid product wrongdoings. Journal of Marketing 77(3): 81-100.

Robert, P. W. and Dowling, G. R. (2002) Corporate reputation and sustained superior financial performance. Strategic Management Journal 23(12): 1077-1093.

Roehm, M.L. and Brady, M.K. (2007) Consumer responses to performance failures by high-equity brands. Journal of Consumer Research 34(4): 537-545.

Rose, R.L. and Wood, S.L. (2005) Paradox and the consumption of authenticity through reality television. Journal of Consumer Research 32(2): 284-296.

Samaraweera, G. C., Li, C. and Qing, P. (2014) Mitigating product harm crises and making markets sustainable: How does national culture matter?. Sustainability, 6(5): 2642-2657.

Schouten, J.W. and McAlexander, J.H. (1995) Subcultures of consumption: An ethnography of the new bikers. Journal of Consumer Research 22(1): 43-61.

Shklar, J.N. (1984) Ordinary Vices. New York: Harvard University Press.

Sohn, Y.J. and Lariscy, R.W. (2010) A “buffer” or "boomerang?” - The role of corporate reputation in bad times. Comunication Research 42(2): 237-259.

Tattri, J. (2009) Maple Leaf's handling of listeria crisis set 'the gold standard,' experts say. Metro News, http:/www.metronews.ca/news/2009/02/20/maple-leafs-handlingof-listeria-crisis-set-the-gold-standard-experts-say.html, accessed November 2016. 
Thomson, M., MacInnis, D.J. and Park, C.W. (2005) The ties that bind: Measuring the strength of consumers' emotional attachments to brands. Journal of Consumer Psychology 15(1): 77-91.

Trump, R.K. (2014) Connected consumers' responses to negative brand actions: The roles of transgression self-relevance and domain. Journal of Business Research, 67(9): 1824-1830.

Van Heerde, H., Helsen, K. and Dekimpe, M.G. (2007) The impact of a product-harm crisis on marketing effectiveness. Marketing Science 26(2): 230-245.

Wagner, T., Lutz, R.J. and Weitz, B.A. (2009) Corporate hypocrisy: Overcoming the threat of inconsistent corporate social responsibility perceptions. Journal of Marketing 73(6): 77-91.

Ward, M.K. and Dahl, D.W. (2014) Should the devil sell prada? Retail rejection increases aspiring consumers' desire for the brand. Journal of Consumer Research 41(3): 590-609.

Wartick, S. L. (1992) The relationship between intense media exposure and change in corporate reputation Business and Society, 31: 33-49.

Weiner, B. (1985) An attributional theory of achievement motivation and emotion. Psychological Review 92(4): 548-560.

Winer, B. (1971) Statistical Principles in Experimental Design. New York: McGrawHill.A 


\section{Appendix A}

Advertisement, authentic brand

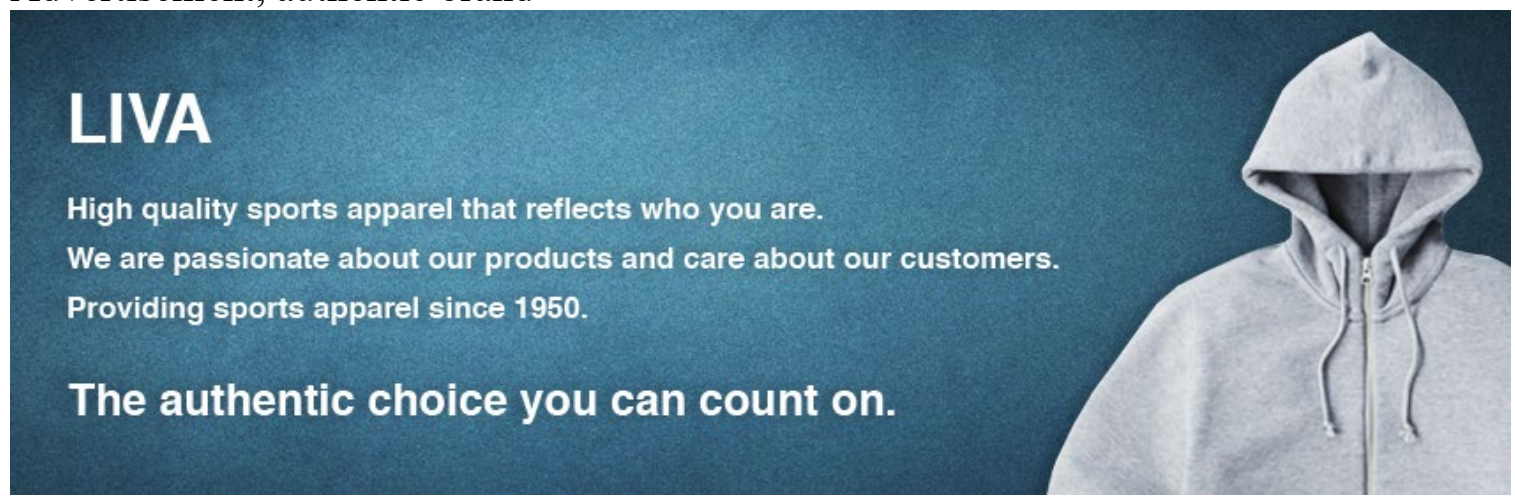

Advertisement, less authentic brand

\section{LIVA}

High quality sports apparel for all your activities.

We offer our customers a variety of styles, fabrics, and colors. Providing sports apparel since 2013.

The athletic choice for your activities. 


\section{Appendix B}

Advertisement, young brand

\section{LIVA}

High quality sports apparel.

Since 2015.

The choice for your activities.

Advertisement, old brand

\section{LIVA}

High quality sports apparel. Since 1950.

The choice for your activities. 